\title{
LETTER
}

\section{Back to basics in sepsis treatment: critically ill patients need intensive care}

\author{
Jack JM Ligtenberg ${ }^{1 *}$, Jaan C ter Maaten ${ }^{1}$ and Jan G Zijlstra ${ }^{2}$ \\ See related viewpoint by Marik and Bellomo, http://ccforum.com/content/17/2/305
}

Marik and Bellomo reason that stress hyperglycemia might be an essential survival response [1]. We reviewed the same question in this journal, before multi-center studies on glycemic control were published [2]. It strikes us that of almost all novel therapies in septic patients, few appear to withstand time. If everything has been futile, did we cause iatrogenic damage, as suggested [1], and is there reason to become cynical? We think the original studies gave rise to good developments. First, the Rivers protocol led to the implementation of limited sepsis treatment bundles resulting in a mortality decrease. Second, the results and the glycemic control of studies by Greet van den Berghe appeared to be not that simple to achieve in real life. Third, lactate-guided therapy improved outcomes, although without an exactly known mechanism [3]. Fourth, a subset analysis of the Surviving Sepsis Campaign database including nearly 9,000 patients revealed that low-dose steroid treatment is associated with an increase in hospital mortality [4]. Fifth, look at all the hemodynamic optimization trials... Notwithstanding the disappointing results of follow-up studies, the original studies were important because they increased recognition of septic patients, led to more original ideas [5], and to effective treatment bundles not funded by third parties [6]. An important common denominator is the intensive attention that all these studies required for their execution, increasing the recognition of septic patients and re-evaluating treatment in a timely manner. These initial studies should make us humble and proud at the same time.

\section{Authors' response \\ Paul E Marik and Rinaldo Bellomo}

We thank Dr Ligtenberg and colleagues for their comments regarding our paper on stress hyperglycemia [1]. We would argue that tight glycemic control may have led to patients receiving therapy that was harmful (too much insulin) [7], that the Rivers protocol has not been validated and may have led to harm (too much fluid, too much blood) $[8,9]$ and that lactate-guided therapy is a misnomer as an oxygen debt is unlikely in sepsis and this approach will lead to excessive interventions (too much fluid, inotropic agents and blood) [10,11]. The steroid effect reported from the Surviving Sepsis Campaign database may just represent selection bias [4]. We advocate a healthy dose of skepticism rather than cynicism. Furthermore, when it comes to the critically ill, 'less may be more' [12].

\footnotetext{
* Correspondence: j.j.m.ligtenberg@umcg.nl

${ }^{1}$ Emergency Department, University Medical Center Groningen (UMCG), NL-9700 RB, Groningen, the Netherlands

Full list of author information is available at the end of the article
}

Competing interests

The authors declare they have no competing interests.

\section{Author details}

'Emergency Department, University Medical Center Groningen (UMCG), NL-9700 RB, Groningen, the Netherlands. ${ }^{2}$ Critical Care Department, University Medical Center Groningen (UMCG), NL-9700 RB, Groningen, the Netherlands.

Published: 31 Jan 2014

\section{References}

1. Marik PE, Bellomo R: Stress hyperglycemia: an essential survival response! Crit Care 2013, 17:305.

2. Corstjens AM, van der Horst ICC, Zijlstra JG, Groeneveld ABJ, Tulleken JE, Zijlstra F, Ligtenberg JJM: Hyperglycemia in critically ill patients - marker or mediator of mortality. Crit Care 2006, 10:216.

3. de Ruiter J, Zijlstra JG, Ligtenberg JJM: Does lactate-guided therapy really improve outcome? Am J Respir Crit Care Med 2011, 183:680-681.

4. Casserly B, Gerlach H, Phillips GS, Lemeshow S, Marshall JC, Osborn TM, Levy MM: Low-dose steroids in adult septic shock: results of the Surviving Sepsis Campaign. Intensive Care Med 2012, 38:1946-1954.

5. Marik PE, Bellomo R: Re-thinking resuscitation goals: an alternative point of view. Crit Care 2013, 17:458. 
6. Zijistra JG, Monteban WE, Tulleken JE, Meertens JHJM, Ligtenberg JJM: Septic shock therapy: the recipe or the cook? Crit Care Med 2006, 34:2870.

7. NICE-SUGAR Study Investigators, Finfer S, Liu B, Chittock DR, Norton R, Myburgh JA, McArthur C, Mitchell I, Foster D, Dhingra V, Henderson WR, Ronco JJ, Bellomo R, Cook D, McDonald E, Dodek P, Hébert PC, Heyland DK, Robinson BG: Hypoglycemia and risk of death in critically ill patients. N Engl J Med 2012, 367:1108-1118.

8. Marik PE: Surviving sepsis: going beyond the guidelines. Ann Intensive Care 2011, 1:17.

9. Fuller BM, Gajera M, Schorr C, Gerber D, Dellinger RP, Parrillo J, Zanotti S: The impact of packed red blood cell transfusion on clinical outcomes in patients with septic shock treated with early goal directed therapy. Indian J Crit Care Med 2010, 14:165-169.

10. Marik PE, Bellomo R: Lactate clearance as a target of therapy in sepsis: a flawed paradigm. OA Crit Care 2013, 1:3.

11. Garcia-Alvarez M, Marik PE, Bellomo R: Stress hyperlactemia. Lancet Endo Diabetes 2014. in press

12. Knox M, Pickers P: "Less is more" in critically ill patients. Not too intensive. JAMA Intern Med 2013, 173:1369-1372.

$10.1186 / \operatorname{cc} 13714$

Cite this article as: Ligtenberg et al.: Back to basics in sepsis treatment: critically ill patients need intensive care. Critical Care 2014, 18:405 